\title{
Evaluation of Baker's Yeast (Saccharomyces cereviciae) In Enhancing Non Specific Immune Response and Growth of Nile Tilapia (Oreochromis niloticus)
}

\author{
Usy N. Manurung, Henky Manoppo, Reiny A. Tumbol
}

\begin{abstract}
ABSTRACK
This research was conducted to evaluate the efficacy of baker's yeast in enhancing nonspecific immune response and growth of Nile tilapia. After two weeks of acclimatization in fiber tank, juveniles were put into glass aquarium at the density of 15 fish/aquarium. Fish were fed pellet supplemented with baker's yeast as treatment for four weeks at $5 \%$ of body weight per day, twice daily (08.00 and 17.00). Five doses of treatment used in this research were A (0 g yeast/kg pellet), B (10 g yeast/kg pellet), C (20 g yeast/kg pellet), D (30 g yeast/kg pellet), E (40 g yeast/kg pellet), Immune parameters included total leucocyte count (TLC) and phagocytosis activity were measured at the end of experiment. Fish growth was weighing at the end of research period. Anova was used to evaluate the effect of baker's yeast on immune parameters and growth while to evaluate the different effect between treatment, Duncan test was used. Research result showed that after four week of feeding, TLC of fish fed diet supplemented with baker's yeast significantly different compared to control fish. The highest TLC of fish was achieved in treatment B followed by treatment C. It was also found that phagocytosis activity of fish increased significantly in fish fed treatment diet with the highest PA was observed in treatment $\mathrm{C}$. PA of fish in treatment $\mathrm{C}$ was different significantly compared to a treatment $\mathrm{A}, \mathrm{D}$ and $\mathrm{E}$ but between treatment $\mathrm{C}$ and $\mathrm{B}$, no significant difference was observed. Application of baker's yeast in diet also significantly increased growth of fish $(p=0,00)$. Fish fed diet supplemented with $20 \mathrm{~g}$ baker's yeast/kg pellet has the highest weight gain compared to other fish in other treatments. It was concluded that the used of baker's yeast at 20-30 g/kg pellet for four weeks could enhance nonspecific immune response and growth of Nile tilapia.
\end{abstract}

Keywords: Saccharomyces cereviciae, total leucocyte count (TLC), Phagocytosis Activity, growth, Oreochromis niloticus

\section{PENDAHULUAN}

Imunostimulan merupakan suatu bahan yang dapat meningkatan sistem pertahanan tubuh ikan melalui peningkatan respon imun nonspesifik ikan. Dari berbagai imunostimulan yang banyak digunakan dalam budidaya ikan maupun udang, ragi roti menawarkan suatu alternatif bagi pengguna antibiotik dan bahanbahan kimia, karena penggunaan ragi roti tidak meninggalkan residu dalam tubuh ikan maupun lingkungan. Produk samping (yeast-by product) dari industri ragi roti juga dapat meningkatkan respon imun non spesifik dan pertumbuhan beberapa spesies ikan (OliviaTeles and Goncalves, 2001). Ragi hidup meningkatkan pencernaan pakan dan protein sehinggga menghasilkan pertumbuhan dan efisiensi pakan yang lebih baik (Wache' et al., 2006). Penambahan 1 g ragi roti per kg pakan selama 12 minggu pada ikan nila (Oreochromis niloticus $L$ ), dapat meningkatkan performa pertumbuhan dan pengambilan pakan serta meningkatkan respon imun non spesifik (Abdel-Tawwab et al., 2008). Penelitian ini 
bertujuan untuk mengevaluasi pengaruh ragi roti sebagai imunostimulan terhadap respon imun non spesifik dan pertumbuhan ikan nila dan untuk menentukan dosis optimal yang dapat meningkatkan kedua parameter ini.

\section{BAHAN DAN METODE}

\section{Hewan Uji}

Hewan uji adalah ikan nila (Oreochromis niloticus) 150 ekor ikan nila, berukuran 8-10

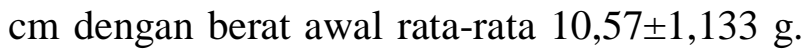
Ikan uji diambil dari Balai Pengembangan dan Pembinaan Pembudidayaan Ikan (BP3I) Tateli. Penelitian ini dilaksanakan di Balai Pengembangan dan Pembinaan Pembudidayaan Ikan, Balai Pengendalian Hama Penyakit Ikan dan Kesehatan Lingkungan, Dinas Kelautan dan Perikanan Provinsi Sulawesi Utara dan Laboratorium Patologi dan Klinik Penyakit ikan Fakultas Perikanan dan Ilmu Kelautan UNSRAT.

\section{Bahan Uji}

Bahan uji ragi roti komersil dengan komposisi: Ragi (Saccharomyces cereviciae) dan pengemulsi (sorbitan monostearate). Pakan Pellet tenggelam merek Comfeed dengan kandungan protein $35 \%$, lemak $5 \%$ dan serat $6,5 \%$.

\section{Persiapan Pakan}

Ragi roti pertama-tama ditimbang sesuai dengan dosis yang dibutuhkan, kemudian ragi roti yang telah ditimbang dilarutkan ke dalam $100 \mathrm{ml}$ air. Ragi roti yang larut/tersuspensi dalam air, kemudian dicampur pada pellet ikan secara merata, selanjutnya dikering-anginkan dalam suhu ruang. Setelah kering, pakan di coating dengan kuning telur dan kemudian dikering-anginkan kembali. Setelah kering, pellet dimasukan dalam kantong plastik dan disimpan dalam lemari pendingin sampai saat digunakan.

\section{Prosedur Percobaan dan Pengambilan Data}

Ikan uji sebelum digunakan dalam penelitian diaklimatisasi terlebih dahulu selama
2 minggu di dalam bak fiber. Selama aklimatisasi, ikan diberi pakan pellet komersil (comfeed), dengan dosis 5\% dari berat tubuh ikan/hari dan diberikan dua kali sehari yaitu jam 08.00 dan jam 17.00. Selama penelitian, suhu air 28-30 ${ }^{\circ}$, DO 5,2-5,4 Ppm, pH 6,0-6,9.

Setelah proses aklimatisasi, ikan dimasukan ke dalam 5 akuarium kaca yang berukuran 50x30x30cm, dengan kepadatan 15 ekor/akuarium dan setiap akuarium dilengkapi dengan aerator. Selanjutnya ikan diberi pakan perlakuan sesuai dosis yang di tetapkan sebagai perlakuan. Perlakuan yang dicobakan adalah $\mathrm{A}=0 \mathrm{~g} / \mathrm{kg}$ pakan, $\mathrm{B}=10 \mathrm{~g} / \mathrm{kg}$ pakan, $\mathrm{C}=20 \mathrm{~g} / \mathrm{kg}$ pakan, $\mathrm{D}=30 \mathrm{~g} / \mathrm{kg}$ pakan, $\mathrm{E}=40 \mathrm{~g} / \mathrm{kg}$ pakan. Pakan perlakuan diberikan dengan dosis dan waktu pemberian yang sama seperti pada waktu aklimatisasi. Data yang dikumpulkan dalam penelitian ini terdiri dari data parameter imun yaitu TLC (Total Leukosit Count), aktifitas fagositosis dan data pertumbuhan mutlak ikan $\Delta \mathrm{G}$.

\section{Parameter Imun}

a. Total Leukosit

Untuk pengukuran parameter imun maka dilakukan pengambilan sampel darah ikan yang dikerjakan menurut prosedur yang dikemukakan oleh Stolen et al. (1990). Sampel darah ikan diambil dari 3 ekor ikan dari setiap akuarium dengan menggunakan spuit $1 \mathrm{ml}$ yang sebelumnya sudah dibilas dengan heparin anti pembekuan darah. Darah diambil dari vena caudalis.

Untuk menghitung jumlah leukosit, darah diambil sebanyak $50 \mu$ dengan mikro pipet dan dimasukan ke dalam tabung eppendorf yang sudah disiapkan sebelumnya. Larutan Turk's diambil sebanyak $500 \mu$ l dan dimasukan ke dalam tabung eppendorf yang telah berisi darah sebelumnya dengan perbandingan darah dan larutan Turk's 1:10. Larutan Turk's dibuat dengan cara mencampurkan $1 \mathrm{ml}$ asam asetat ke dalam 100 ml akuades. Fungsi larutan Turk's adalah untuk menghancurkan sel darah merah. Campuran darah dan larutan Turk's dihomogenkan dengan mengayun-ayunkan secara perlahan- 
lahan dan diinkubasi dalam suhu ruang selama 5 menit, salanjutnya dilakukan penghitungan total leukosit dengan menggunakan haemacytometer dengan bantuan mikroskop cahaya pada pembesaran 100x.

\section{b. Aktifitas Fagositosis}

Pengukuran aktifitas fagositik dilakukan dengan cara: pertama-tama sampel darah sebanyak 50 $\mu$ l yang telah disiapkan sebelumnya dimasukan ke dalam tabung eppendorf steril dan ditambahkan 50 $\mathrm{\mu l}$ suspensi zymosan (Zigma Aldrick). Larutan campuran darah dan zymosan ini selanjutnya dihomogenkan dengan cara diayunkan perlahan-lahan dan diinkubasi dalam suhu ruang selama 20 menit. Selanjutnya $5 \mu \mathrm{l}$ sampel campuran darah dan zymosan dibuat sediaan ulas dan dikering-anginkan dalam suhu ruang. Proses selanjutnya adalah melakukan pewarnaan Giemsa. Proses pewarnaan sediaan ulas dengan Giemsa dikerjakan sesuai dengan prosedur (Pritchard and Kruse, 1988):

Sel yang menunjukan proses fagositosis yang ditandai dengan adanya sel-sel zymosan yang menempel pada permukaan sel fagosit atau terdapat di dalam sitoplasma sel dan dihitung dari 50 sampai 100 sel yang teramati. Aktifitas fagositosis dihitung dengan rumus:

Aktifitas Fagositosis (\%) =

Jumlah fagosit yang melakukan pemangsaan $\quad$ x 100

$$
\text { Jumlah fagosit teramati }
$$

\section{Pertumbuhan}

Penimbangan berat ikan dikerjakan pada akhir penelitian yaitu minggu ke 4 . Pertumbuhan mutlak dihitung berdasarkan selisih antara berat ikan pada akhir percobaan dan berat ikan pada awal percobaan dengan formula (Effendie 1989) :

$$
\Delta \mathrm{G}=\mathrm{Wt}-\mathrm{Wo}
$$

Dimana:

$$
\begin{aligned}
& \Delta \mathrm{G}=\text { Pertumbuhan }(\mathrm{g}) \\
& \mathrm{Wt}=\text { Berat pada waktu } \mathrm{t}(\mathrm{g}) \\
& \mathrm{Wo}=\text { Berat pada awal percobaan }(\mathrm{g})
\end{aligned}
$$

\section{Analisis Data}

Data parameter imun maupun pertumbuhan yang diperoleh dinyatakan dalam bentuk nilai rata-rata \pm Stdv. Untuk melihat pengaruh perlakuan ragi roti terhadap respon imun non spesifik dan pertumbuhan ikan, maka dilakukan analisis ragam sedangkan untuk menguji perbedaan pengaruh antar perlakuan, dilakukan uji lanjut Duncan.

\section{HASIL DAN PEMBAHASAN}

\section{Parameter Imun}

a. Total Leukosit

Total leukosit ikan uji dapat yang dihitung pada akhir penelitian dapat dilihat pada Gambar 1.

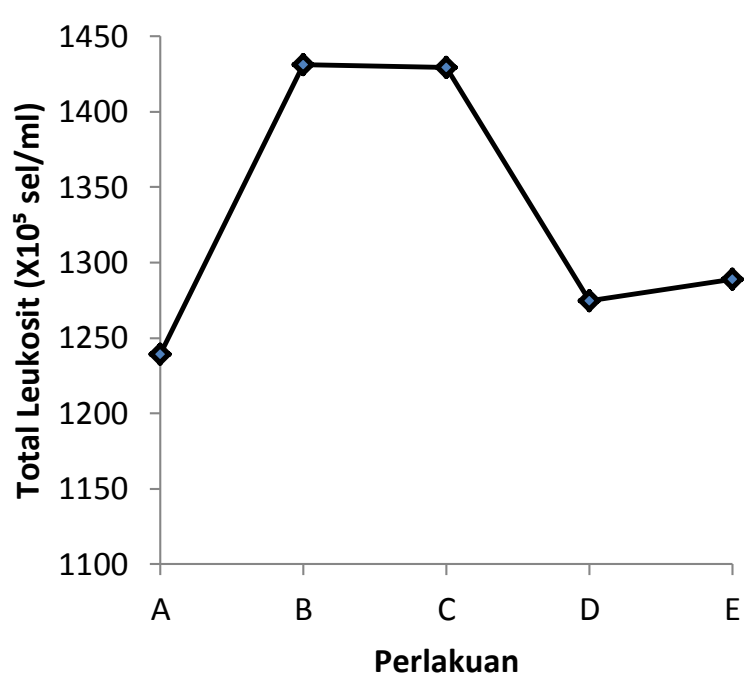

Tabel 1. Total Leukosit Rata-Rata (x10 $\mathrm{sel} / \mathrm{ml})$ Ikan Nila Setelah Diberi Perlakuan Ragi Roti Selama 4 Minggu Percobaan

Gambar di atas menunjukan bahwa penambahan ragi roti dalam pakan ikan nila dapat merangsang peningkatan jumlah leukosit ikan. Pada penelitian ini, ditemukan bahwa total leukosit tertinggi dicapai pada perlakuan B (10 g ragi roti), diikuti oleh perlakuan C (20 g ragi roti). Hasil analisis ragam menunjukan bahwa penambahan ragi roti pada pakan ikan 
dan diberikan selama 4 minggu berpengaruh sangat nyata $(\mathrm{p}=0,00)$.

Hasil penelitian ini menunjukan bahwa penambahan ragi roti dalam pakan ikan nila dapat merangsang peningkatan jumlah leukosit ikan. Hasil yang sama dilaporkan oleh Tewary and Patra (2011) dimana ikan Labeo Rohita berukuran rata-rata $12 \mathrm{~g}$ yang diberi pakan dengan penambahan ragi roti $5 \%$ memiliki total leukosit yang lebih tinggi dibandingkan dengan ikan yang tidak diberi pakan dengan penambahan ragi roti. Hasil penelitiannya juga menunjukan bahwa selain meningkatkan total leukosit, penambahan ragi roti juga mampu merangsang pertumbuhan ikan. Hal ini disebabkan ragi roti mengandung bahan-bahan yang berfungsi sebagai imunostimulator seperti nukleotida (Li and Gatlin, 2003). Menurut Barnes (2006), nukleotida merupakan nutrient semi esensial yang dibutuhkan untuk pertumbuhan dan perbanyakan sel. Sajeevan et al., (2006), juga menyatakan bahwa nukleotida yang ditambahkan dalam pakan dapat mengoptimalkan fungsi pembelahan sel, termasuk sel-sel imun. Dalam hal ini nukleotida akan diurai oleh nukleotridase untuk melepaskan molekul fosfat dan menghasilkan nukleosida. Nukleosida selanjutnya diurai oleh nukleosidase atau nucleoside phosphorylase untuk melepaskan molekul gula dan menghasilkan basa purin dan pirimidin. Nukleosida dan basa nitrogen akan diserap oleh usus untuk selanjutnya disintesa kembali membentuk nukleotida yang dibutuhkan untuk replikasi DNA dan sintesa RNA dalam pembelahan sel (Delvin, 2002). Ragi roti juga mengandung $\beta$-glucan (Raa, 2000), $\beta$-glucan ini akan berikatan dengan sel-sel fagosit dimana setelah berikatan, sel akan mengeluarkan molekul-molekul signal (sitokin) yang merangsang pembentukan sel fagosit yang baru.

\section{b. Fagositosis}

Hasil penghitungan aktifitas fagositosis ikan nila (Oreochromis niloticus) yang dihitung pada akhir periode penelitian dapat dilihat pada Gambar 2.

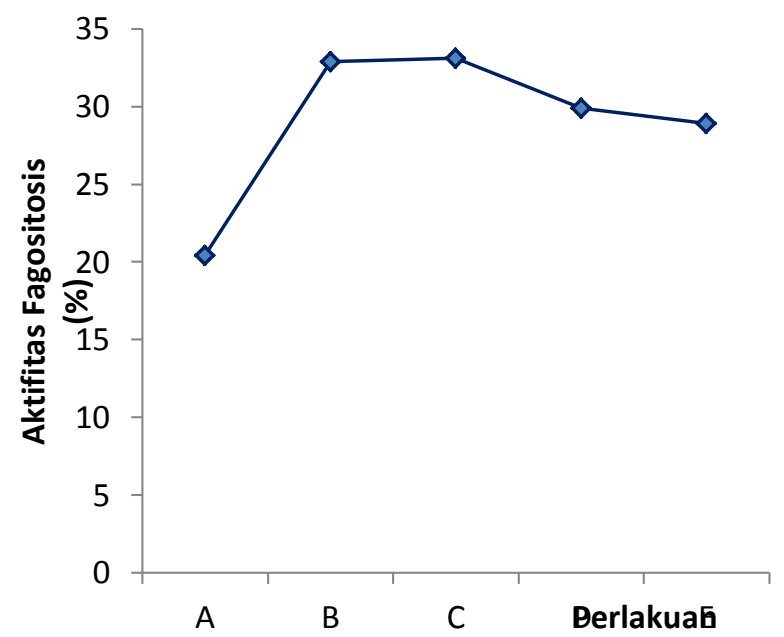

Gambar 2. Aktifitas Fagositosis Rata-Rata Yang Diberi Perlakuan Ragi Roti Selama 4 Minggu.

Data pada gambar di atas menunjukan bahwa penambahan ragi roti dalam pakan ikan nila dapat merangsang peningkatan jumlah aktifitas fagositosis ikan. Pada penelitian ini, didapat bahwa aktifitas fagositosis tertinggi dicapai pada perlakuan C (20 g ragi roti), diikuti oleh perlakuan B (10 g ragi roti). Hasil analisis ragam menunjukan bahwa penambahan ragi roti pada pakan ikan nila (Oreochromis niloticus) dan diberikan selama 4 minggu berpengaruh sangat nyata $(p=0,00)$.

Hasil penelitian memperlihatkan bahwa penambahan ragi roti dalam pakan berpengaruh sangat nyata terhadap aktifitas fagositosis dari sel-sel fagosit. Hasil uji lanjut Duncan, dimana pada minggu ke 4 perlakuan $\mathrm{C}$ dan $\mathrm{B}$ berbeda sangat nyata $(\mathrm{p}=0,00)$, dibandingkan dengan perlakuan A maupun dengan perlakuan $\mathrm{D}$ dan E. Sekalipun demikian, antara perlakuan B dan C secara statistik tidak berbeda nyata, namun secara kuantitatif aktifitas fagositosis pada perlakuan $\mathrm{C}$ lebih tinggi dibandingkan dengan perlakuan B.

Ragi roti selain mengandung nukleotida yang dibutuhkan untuk perbanyakan sel, juga mengandung bahan-bahan imunomudulator seperti asam nuclei, mannan dan $\beta$-glucan yang dapat meningkatkan respon imun ikan ( $\mathrm{Li}$ and Gatlin, 2006). $\beta$-glucan yang terdapat dalam 
ragi roti dapat mengikat pada molekul reseptor yang terdapat pada permukaan sel-sel fagosit (Raa, 2000). Pada saat reseptor berikatan dengan $\beta$-glucan maka sel fagosit akan menjadi lebih aktif dalam melakukan fagositosis pada partikel asing atau bakteri. Hasil yang sama ditunjukan pada penelitian ini, dimana penambahan ragi roti pada dosis (20 g) yang diberikan selama 4 minggu dapat meningkatkan aktifitas fagositosis ikan uji. Dalam penelitian yang dilakukan oleh Sakai et al., (2001), ikan mas yang diberi ekstrak ragi roti $15 \mathrm{mg} / \mathrm{ikan}$ selama 3 hari memperlihatkan peningkatkan aktifitas fagositosis pada ikan (Oreochromis niloticus).

\section{Pertumbuhan}

Tabel 3. Berat Rata-Rata Ikan (Gram) Setelah Diberi Pakan Dengan Penambahan Ragi Roti Selama 4 Minggu.

\begin{tabular}{lccc}
\hline Perlakuan & $\mathrm{W}_{0}$ & $\mathrm{Wt}$ & $\mathrm{Wt}-\mathrm{W}_{0}$ \\
\hline $\mathrm{A}$ & 10,57 & 14 & $3,4300 \pm 2,00$ \\
$\mathrm{~B}$ & 10,57 & 18,6666 & $8,0967 \pm 1,52$ \\
C & 10,57 & 17,6666 & $7,0967 \pm 1,52$ \\
D & 10,57 & 15,6666 & $5,0967 \pm 0,57$ \\
E & 10,57 & 15,3333 & $4,7633 \pm 0,57$ \\
\hline
\end{tabular}

Hasil penelitian memperlihatkan bahwa penambahan ragi roti dalam pakan berpengaruh sangat nyata terhadap pertumbuhan ikan uji. Dari hasil penelitian terlihat bahwa perlakuan B jika diberikan selama 4 minggu memberikan hasil yang terbaik terhadap perolehan berat ikan. Pertumbuhan mutlak ikan pada perlakuan B mencapai 8,09 g, sedangkan pada kontrol pertumbuhan mutlak hanya mencapai 3,34 g.

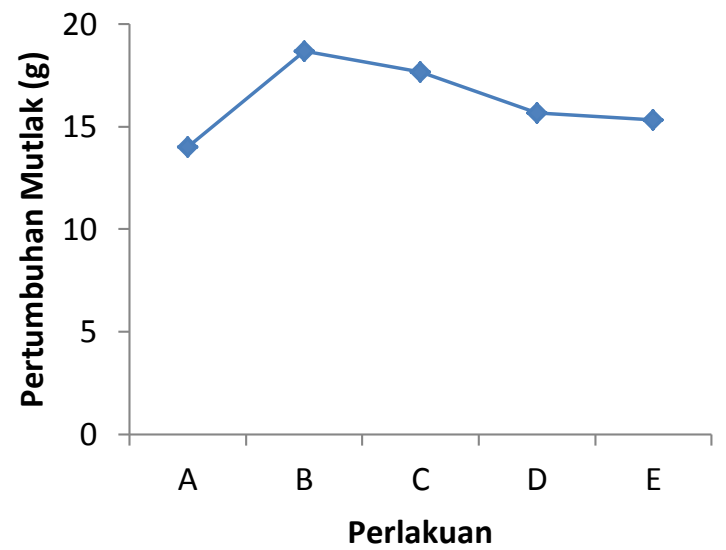

Data pada gambar di atas menunjukan bahwa penambahan ragi roti dalam pakan ikan nila meningkatkan pertumbuhan ikan. Pada penelitian ini, didapat bahwa penambahan ragi roti tertinggi dicapai pada perlakuan B (10 g ragi roti), diikuti oleh perlakuan $\mathrm{C}$ (20 g ragi roti). Hasil analisis ragam menunjukan bahwa penambahan ragi roti pada pakan ikan dan diberikan selama 4 minggu berpengaruh sangat nyata $(\mathrm{p}=0,00)$ terhadap pertumbuhan ikan nila (Oreochromis niloticus).

Penambahan ragi roti dapat meningkatkan pertumbuhan karena ragi roti mengandung nukleotida. Menurut $\mathrm{Li}$ and Galtin (2006), ragi roti mengandung nukleotida dalam bentuk basah purin dan pirimidin sebanyak 0,9 \%. Hasil penelitian Lin et al., (2009) menunjukan bahwa penambahan nukleotida dalam pakan ikan kerapu yang diberikan selama 8 minggu, dapat meningkatkan perolehan berat ikan yang lebih besar dibandingkan dengan ikan yang diberi pakan tanpa pemberian nukleotida. Tewary and Patra (2011) melaporkan bahwa ikan Labeo rohita yang diberi pakan dengan penambahan ragi roti 5 \% dan diberikan selama 60 hari, memiliki perolehan berat yang lebih besar dibandingkan dengan pertumbuhan ikan yang tidak diberi ragi roti. Hasil penelitian Burrels et. al. (2001) juga menunjukan bahwa, pertumbuhan ikan salmon meningkat setelah diberi pakan dengan penambahan nukleotida selama 8 minggu. Pada udang hasil penelitian Manoppo dkk. (2011), menunjukan bahwa udang yang diberi nukleotida 400 mg. $\mathrm{kg}^{-1}$ 
pellet, memiliki berat akhir yang lebih besar, jika dibandingkan dengan udang yang tidak diberi pakan dengan penambahan nukleotida. Ozorio et al., (2010) melakukan penelitian pada ikan pacu (piaractus mesopotamicus) 26 g, untuk mengganti tepung ikan dengan ragi roti. Hasil penelitiannya menunjukan bahwa penggantian tepung ikan sebanyak $50 \%$ dengan ragi roti dan diberikan selama 54 hari secara nyata meningkatkan efisiensi pakan dan pertumbuhan ikan.

Nukleotida merupakan imunostimulan yang cukup mahal untuk digunakan dalam aktifitas budidaya, oleh karena itu perlu dicari bahan pengganti yang murah dan mengandung nukleotida yang tinggi. Ragi roti merupakan bahan yang mengandung nukleotida yang tinggi sehingga dapat digunakan sebagai pengganti nukleotida murni. Hasil penelitian Abdel-Tawwab et al., (2008) menunjukan bahwa penambahan $1 \mathrm{~g}$ ragi roti per kg pakan yang diberikan selama 12 minggu pada ikan nila (Oreochromis niloticus L), dapat meningkatkan pertumbuhan dan pengambilan pakan serta meningkatkan respon imun non spesifik dan resistensi terhadap infeksi (Aeromonas hydrophila). Wache' et al., (2006) juga mendapatkan hasil penelitian bahwa, penambahan ragi roti akan meningkatkan pencernaan pakan dan protein sehingga menghasilkan pertumbuhan dan efisiensi pakan yang lebih baik. Sakai et al., (2001) melaporkan bahwa nukleotida yang diekstrak dari ragi roti dan ditambahkan dalam pakan ikan nila, dapat meningkatkan proses fagositosis, oxidativ radical sel fagositik ginjal, dan lysozyme serta meningkatkan resistensi terhadap infeksi A. hydrophila. Produk samping dari industri ragi roti juga dapat digunakan sebagai suplemen pakan dan telah diketahui memberi pengaruh positif terhadap pertumbuhan dan respon imun non spesifik beberapa spesies ikan (Olivia-Teles and Goncalves, 2001). Nukleotida dapat meningkatkan pertumbuhan kerena nukleotida yang terkandung dalam ragi roti dapat meningkatkan nafsu makan ikan sehingga pengambilan pakan meningkat (Burrels et al., (2001).

\section{KESIMPULAN}

Penambahan ragi roti dalam pakan sebanyak 10-20 g/kg pakan dan diberikan selama 4 minggu berturut-turut dapat meningkatkan respon imun nonspesifik dan pertumbuhan ikan nila

\section{DAFTAR PUSTAKA}

Abdel-Tawwab M, A.M. Abdel-Rahman and N.E.M. Ismael. 2008. Evaluation of commercial live baker's yeast, Saccharomyces cereviciae as a growth and immunity promoter for fry Nile Tilapia Oreochromis niloticus (L) challenged in situ with Aeromonas hydrophila Aquaculture 280:185-189.

Barnes, A. 2006. Dietary nucleotides: Essential nutrients for shrimp growth and immunity. Centre for Marine Studies, University of Queensland.

Burrels, C., P. D. Williams and P. F. Fomo. 2001. Dietery Nucleotide: a novel upplement in fish feed. 1 effects on resistance to disease in In Salmonids. Aquac 199: 159-169.

Effendie, M.I. 1979.Metode Biologi Perikanan. Bogor

Li, P and D.M. Gatlin III. 2003. Evaluation of brewers' yeast. (Saccharomyces cereviciae) as a feed supplement for hybrid striped bass (Marone chrysops x M. saxatillis). Aquac 219: 681-692

Li, P and D.M. Gatlin III. 2006. Nucleotide nutrition in fish: Current knowledge and fiture application. Aquac 251 : $141-152$.

Lin, Y.H., H. Wang and S. Y. Shiau. 2009. Dietary nucleotide supplementation enhance growth and immune response of grouper, Epinephelus malabaricus. Aquac 15: 117-122.

Manoppo, H. 2011. Peran Nukleotida Sebagai Imunostimulan Terhadap Respon 
Imun Non spesifik dan Resistensi Udang Vaname (Litopenaeus vannamei). Pascasarjana IPB (Disertasi). Bogor.

Olivia-Teles A. and P. Goncalves. 2001. Partisial replacement of fishmeal by brewers yeast Saccaromyces cerevisiae, in diets for sea bass Dicentrachus labrax juveniles. Aquaculture 202: 269'278.

Ozorio, R. O. A., B. G. S. Turini, G. V. Moro, L. S. T. Oliveira, L. Portz and J.E.P. Cyrino. 2010. Growth, nitrogen gain and indispensable amino acid retention of pacu (Piaractus mesopotamicus, Holmberg 1887) fed different brewers yeast (Saccaromyces cerevisiae) levels.

Pritchard, M. H. and G. O. W. Kruse. 1982. The Collection and Preservation of Animal Parasites. University of Nebraska Press, London.

Raa, J. 2000. The use of immune-stimulants in fish and shellfish feeds. University of Tromso Norway.

Sajeevan, T. P., R. Philip and I.S.B. Singh. 2006. Immunostimulatory effect of a marine yeast Candida sake S156 Fenneropenaeus indicus. Aquac 257: 150-155.

Sakai, M., K. Taniguchi., K. Mamoto., H. Ogawa and M. Tabata. 2001. Immunostimulant effects of nucleotide isolated from yeast RNA on crap, Cyprinus carpio L. J Fish Dis 24: 433438.

Stolen, S. J. 1990. Techniques in immunologi. 1 st edition. SOS Publication 43 de Normandie A Venue Fair Haven, NJ 07703-3303.

Tewary, P., and B. C. Patra. 2011. Oral administration of baker's yeast (Saccharomyces cerevisiae) acts as a growth promoter and immunomodulator in Labeo rohita (Ham.)
Wache', Y., F. Auffray, F. L. Gatesoupe, J. Zurrbonino, V. Gayet, L. Labbe', and C. Quentel. 2006. Cross effect of the strain dietary Saccharomyces cereviciae and rearing conditionon theonset of intestinal microbiota and digestive enzymes in rainbow trout, Olchorhynchus mykiss fry. Aquacultgre 258:470478 